\title{
A national system of biological monitoring in the Russian Arctic as a tool for the implementation of the Stockholm Convention
}

\author{
Tatiana Yu Sorokina ${ }^{1}$ (D)
}

Accepted: 17 April 2019 / Published online: 26 April 2019

(c) The Author(s) 2019

\begin{abstract}
Issues related to protection of the Arctic environment are becoming increasingly urgent, as arctic ecosystems are vulnerable to increasing anthropogenic pressures. The problem of protecting Northern nature from the effects of persistent organic pollutants, which are dangerous for both biota and human health, is particularly acute. This case study analyses the existing normative acts regulating monitoring activities in the Russian Arctic. The paper emphasizes gaps in legal regulation, which are particularly prominent with regard to monitoring the quality of traditional food consumed by indigenous peoples. The author introduces proposals to change the current legislation to improve the efficiency of the state monitoring system in the Russian Arctic. Such changes will also help to harmonize monitoring activities in Russia with other Arctic States and to fill in the gaps in the Global Monitoring Reports and the Arctic Monitoring and Assessment Programme (AMAP) reports on persistent organic pollutants in traditional indigenous food.
\end{abstract}

Keywords Stockholm Convention · Russian Arctic $\cdot$ Environmental monitoring $\cdot$ AMAP

\section{Introduction}

Having ratified the Stockholm Convention on persistent organic pollutants in 2011 (Law No. 164-FZ 2011), the Russian Federation recognized that these pollutants possess toxic properties, resist degradation, bioaccumulate and are transported (through air, water and migratory species) across international boundaries and deposited far from their place of release, where they accumulate in terrestrial and aquatic ecosystems.

It is no secret that persistent organic pollutants (POPs) enter nature through different pathways (during the implementation of some economic activities, after emergency situations, natural disasters, etc.) and subsequently enter the human body, where they can accumulate for years, leading to irreversible health consequences for both individuals and the population as a whole (Dudarev 2012). Permafrost and low annual temperatures protect the

Tatiana Yu Sorokina

t.sorokina@narfu.ru

1 Northern (Arctic), Federal University named after M.V. Lomonosov, Arkhangelsk, Russia 
Arctic from diseases that affect the southern regions. As the planet undergoes the process of climate change, the rise in temperature of the worlds oceans is simultaneously causing the melting of glaciers, thus exposing this area to previously unknown chemical and infectious agents (90 People 2016). It is not only air, land and water bodies (Kosyakov et al. 2017) that are subject to such pollution, animals (Savinov et al. 2011), fish (AMAP 2018), birds (Lucia et al. 2015) and even humans are also adversely affected (AMAP 2015; Dudarev 2012). The indigenous peoples, among others, living in the Northern regions are at greatest risk, as their whole lifestyle, food culture and way of life are built on close cooperation with the wild nature of the Arctic. In this regard, the problem of a timely response to emerging threats to the life and health of the population living in the Arctic zone of the Russian Federation is of particular importance.

In accordance with the provisions of Article 11 of the Stockholm Convention, Russia has pledged to encourage and/or implement, at both the national and international levels, appropriate research, monitoring and cooperation. For such obligations to become mandatory for everyone in their daily activities, it is necessary to adopt a large number of regulations that enshrine the rights and duties of persons involved, and it is also necessary to establish procedures. Today, there is no unified programme of POPs monitoring in the Russian Arctic. The existing systems used to monitor environmental pollution in the Russian Federation are based mainly on quantitative measurements of the content of harmful substances in the atmosphere, water and soil (Order No. 1316-p 2015). At the same time, there is another route by which such substances can enter the human body-migratory species of fish and birds, as well as the meat and fat of wild terrestrial and marine animals (Dudarev 2012). This latter source is particularly dangerous for indigenous peoples as well as for the population that has maintained their traditional way of life and traditional sources of nutrition (Klopov et al. 1998). Thus, health risks for Arctic inhabitants are not fully taken into account under current monitoring systems. Information on POPs in Russia, and in the Russian Arctic in particular, is catastrophically deficient. The objective of this case study is to identify the challenges that do not allow Russia to efficiently integrate to Global monitoring of POPs. At the same time, it is needed to identify possible ways to solve these problems.

\section{Russia and the Stockholm Convention}

The negotiations on the Stockholm Convention on Persistent Organic Pollutants initiated by the UN were concluded on 23 May 2001 in Stockholm. The Convention entered into force on 17 May 2004 upon ratification by an initial 128 parties (a total of 151 parties at that time). The signatories to the Convention set out obligations to prohibit the production and use (except for some items) of the twelve chemicals on the POPs list, to limit the use of DDT for malaria control, and to develop programmes to combat the unintentional formation of dioxins and furans.

The Convention was signed by Russia on 22 May 2002 in New York (Order No. 320 2002). The first ratification attempt was made on 11 October 2004, the second in 2007, but both bills were rejected. Despite this, there was a national strategy and a national focal point (Order No. 583 2002) for the implementation of the POPs Convention. The functions of the national focal point were assigned to the Centre of International Projects of the Ministry of Natural Resources. The tasks of the focal point included: (1) informing the parties and the Secretariat of the Convention and other stakeholders about the reduction or 
elimination of production, use and emissions of POPs; (2) alternatives to POPs; (3) public information, awareness and education (Order No. 822 2003). The functions of the national focal point were established in accordance with Articles 9 and 10 of the Convention.

The Stockholm Convention was ratified only with the adoption of the Federal law of 27.06.2011 No. 164-FZ "On ratification of the Stockholm Convention on persistent organic pollutants". This law ratifies the Convention in the wording of 22 May 2001, that is in the wording with which it was signed in 2002. Russia joined the 2009 and 2011 amendments to the Convention only at the end of 2016 (Order No. 2482-p 2016).

The obligations under the Stockholm Convention required organizational decision making. Thus, in 2014, the Ministry of Natural Resources and Environment was made responsible for coordinating the implementation of the Convention. The Ministry is now responsible for interacting with the Convention Secretariat, preparing and submitting national reports and other materials, and appointing a focal point for the exchange of information. All other Russian ministries were entrusted with the duty to implement the Convention within the limits of their powers. In 2017, a new national focal point was appointed. Now, it is the Novosibirsk Institute of Organic Chemistry named after N. N. Vorozhtsov. At the same time, the spheres of activity of the focal point were detailed (Order No. 57 2017). Thus, by the end of 2017, all the necessary organizational measures were taken to ensure the implementation of the Stockholm Convention in the territory of the Russian Federation.

Not only organizational measures were implemented by Russia, substantial changes were also made in Russian legislation. In 2014, the Federal Law on Environmental Protection (the basic environmental regulatory act in Russia) was amended to include Article 4.1- "Pollutants". Up to this moment, there was no such concept in the Russian legislation, although it was actively used by both the scientific community and officials. The law establishes that pollutants are determined by taking the following into account: (a) the level of toxicity, carcinogenic and (or) mutagenic properties of chemical and other substances, including those that tend to accumulate in the environment, as well as their ability to convert into compounds with higher toxicity in the environment; (b) the data of state environmental monitoring and socio-hygienic monitoring; and (c) the existing methods of measuring pollutants. Afterwards the Government of the Russian Federation adopted a list of pollutants, that are subject to environmental regulation (Order No. 1316-p 2015). In addition to POPs, this list includes a large number of other pollutants. The adoption of this list means nothing less than the selection by the state of priority substances for monitoring and control.

One of the main indicators of the effectiveness of the Stockholm Convention on Persistent Organic Pollutants is the reduction of the pollutants' concentrations in the environment and in human populations. The most visible and effective verification mechanism is systematic monitoring. The Global Monitoring Plan (GMP) is an important component of effectiveness evaluation. The data obtained with a certain periodicity show ongoing changes in pollutant levels, allowing timely management decisions to be made at national and international levels. In this regard, it is very important to establish harmonized national monitoring systems that cover as many monitoring sites as possible. With regard to the monitoring of POPs in the Russian Arctic, three different monitoring systems need to be considered: (1) the Global Monitoring Plan under the Stockholm Convention (international level); (2) The protocols of the Arctic Monitoring and Assessment Programme (regional level); and (3) the Russian state monitoring system (national level). The first two systems do not contradict each other, but are harmoniously implemented complementing each other. This is confirmed by references to AMAP results in both Global Monitoring Reports. 
For more than two decades under the auspices of the Arctic Monitoring and Assessment Programme (AMAP), the most active work on monitoring of pollution levels in the Arctic and their impact on the health of the indigenous population has been carried out. The studies cover the northern territories of all Arctic Nations. A special programme of quality assessment and quality control (QA/QC) has been established for laboratories involved in the analytical work of quantitative pollutant determination (32 laboratories around the world) (Asmund et al. 2004). Under this programme, comprehensive work focuses on the selection of samples for analysis and on the processing of the received results (Dudarev and Odland 2017). The results of scientific research on persistent toxic substances in circumpolar regions are systematized and summarized in four AMAP (1998, 2003, 2009, 2015) reports especially dedicated to human health (Dudarev and Odland 2017: p. 3). It is possible to say that the monitoring system of the AMAP has become the regional standard for conducting observations in the Arctic. However, the recent political trends in the establishment of mutual sanctions, the systematic prohibitions on the export of biological material for research abroad (Vlassov 2007; News.ru 2017) and excessive control over the activities of foreign and international organizations in the territory of the Russian Federation are obstacles to the development of international cooperation in the field of monitoring in the Arctic.

Some AMAP reports (AMAP 2018), both GMP reports and research papers (Adlard et al. 2018; Rigét et al. 2019) indicate an absence or lack of data about Russia and the Russian Arctic in particular. Russia has been conducting scientific research in the Russian Arctic for many years. The dawn of monitoring of the Russian Northern regions occurred in the Soviet period. Since that time, unique materials have been collected, and many research results have been published in Russian scientific journals. In fact, there is a paradoxical situation. Although monitoring is conducted in the Russian Arctic, the Russian Arctic remains a large gap on the international scientific map.

There are several reasons why this happens. Russia is a huge multinational country that united many peoples, cultures and traditions. Despite the fact that the regulation of social relations is mainly carried out at the federal level and extends to the entire territory of the country, the practice of its application may vary in different regions. This can be explained by low executive responsibility of the regional authorities, lack of coordination from above and other factors. However, there are gaps, inaccuracies and controversial issues even with the implementation of Russia's own national monitoring system. Understanding the need for harmonization of POPs monitoring with GMP and AMAP protocols, still there are challenges in implementing this.

\section{Challenges of the global monitoring plan implementation in Russia}

Russia has its own national (state) monitoring system, which has historically developed and is now approved by law. It covers the entire territory of the country, including the Arctic zone of the Russian Federation. National monitoring is initiated and financed by the state. The legislation defines the structure and scope of information forming the monitoring data, responsible state bodies and officials to ensure and organize certain types of observations. On the basis of state monitoring data, as well as state control, state reports are formed and statistics are collected. The existence of such a system does not negate or deny that scientific groups conduct research funded by grants (Russian Foundation for Basic Research, Russian Science Foundation, KolArctic, etc.), government subsidies and 
other sources. Such research can complement and deepen the data of the state monitoring. The state monitoring system is a very effective mechanism for a country as large as Russia. Grants from scientific foundations and other sources of funding for small scientific communities cannot provide the necessary scale of research. The state budget of the country can help to achieve that scale.

Following the adoption of the Stockholm Convention, the Russian national monitoring system is expected to provide the necessary data on POPs concentrations in different objects, possible sources of inputs and the extent of distribution. But at the moment it does not. One of the reasons is the slow response of the Russian legislative process to implement international obligations. As mentioned above, the procedure of ratification of the Convention took almost a decade, and a process of any other necessary additions and changes to the legislation is extremely difficult. Thus, by the time the first Regional Monitoring Report (Holoubek 2008) and the Global Monitoring Report (2009) were published, Russia had not yet ratified the international POPs agreement. The data on Russia reflected in the monitoring reports of that period were obtained from the AMAP project report "Persistent Toxic Substances, Food Security and Indigenous Peoples of the Russian North" (AMAP 2004) and mainly concerned the territory of the Russian Arctic, and rather the content of POPs in breast milk and blood of the indigenous population (human biomonitoring data), than in the objects of nature. Samples were taken between 1998 and 2004. This suggests that the data presented may be very outdated, in particular, due to the improvement of analytical techniques used.

The Second Regional Monitoring (Šebková 2014) and the Second Global Monitoring Report (2017) identified a significant gap in knowledge about Russia. Only not very extensive data on air contamination in the area of several settlements of Russia appeared in the reports. With regard to breast milk and human blood, the documents continued to refer to the AMAP and UNEP work in Russia conducted from 1992 to 2004. As it was mentioned before, during this period, the necessary amendments to the Russian legislation to ensure the implementation of the Stockholm Convention were still being made.

Another challenge in implementing the Global Monitoring Plan in Russia is related to the design of the national monitoring system. Due to the fact that POPs are found both in natural objects and in the human body, the data must be accumulated from two completely different monitoring subsystems: the environmental monitoring subsystem, headed by the Ministry of Natural Resources and Ecology (the one that is assigned to be responsible for the implementation of the Stockholm Convention in the Russian Federation) and the subsystem of social and hygienic monitoring, headed by the Ministry of Health. The differences between these two monitoring subsystems are hidden in the understanding of the basic terms used to determine the object of study: "environment" and "habitat". These terms are determined in the Russian legislation, and on their basis there is a clear distinction of jurisdiction of state authorities. Moreover, the difference in the understanding of these two terms by Russian legal doctrine causes a clear distinction between Environmental Law and Sanitary and Epidemiological Law.

The habitat is a set of objects, phenomena and factors of the surrounding (natural and artificial) environment that determines the conditions of human life (Law No. 52-FZ 1999: art. 1). Therefore, the habitat includes not only nature around us but also our homes, working places and any other areas that influence our life and health. Russia's main environmental regulatory act defines the natural environment (nature) in a very similar way, namely as a set of components of the natural environment, including natural and anthropogenic objects, where an anthropogenic object is an object created by a human to ensure his social needs and does not have the features of natural objects (Law No. 7-FZ 2002: art. 1). At 
the same time, none of any other environmental normative acts regulate the protection of anthropogenic objects. Thus, both concepts, being independent, merge when it comes to the anthropogenic impact on nature and the impact of environmental pollution on human health.

This is the difference in understanding the environment in Russia and in many other countries, as well as in the practice of implementing international environmental agreements. The generally accepted international understanding of the environment is not limited to nature as such, but also includes human living conditions. Thus, as a rule, the two concepts are the same. But not for Russian law.

In this respect, the state environmental monitoring system is a comprehensive programme of state monitoring of the environment, the processes and phenomena occurring in the environment, and the assessment and forecasting of changes (Law No. 7-FZ 2002: art. 1). State environmental monitoring in the Arctic zone of the Russian Federation include (Law No. 7-FZ 2002: art. 63.1):

1. monitoring of the state and pollution of the environment in general (Resolution No. 477 2013);

2. monitoring of the non-living components of nature [e.g. land (Order No. 852 2014), subsoil (Order No. 433 2001), air (Law No. 96-FZ 1999), forests (Forest Code 2006; Order No. 156 2017) and water objects (Decree No. 219 2007)];

3. monitoring of territories [e.g. the exclusive economic zone of the Russian Federation (Law No. 191-FZ 1998), the continental shelf of the Russian Federation (Law No. 187FZ 1995) and the habitat of hunting resources (Order No. 344 2010)];

4. monitoring of the living components of nature [e.g. animal world (Order No. 9632011 ), aquatic biological resources (Decree No. 994 2008), hunting resources (Order No. 344 2010)];

5. monitoring of certain types of pollution [e.g. monitoring of the radiation situation in the Russian Federation (Law No. 170-FZ 1995)].

In accordance with Article 1 of the Federal law on the sanitary and epidemiological welfare of the population, social and hygienic monitoring is the state system of monitoring the health of the population and habitat; analysis, assessment and forecasting; and determining the cause-effect relationships between the health of the population and the impact of habitat factors. Social and hygienic monitoring is conducted by the bodies authorized to carry out the federal state sanitary and epidemiological supervision, in the order established by the Government of the Russian Federation (Decree No. 60 2006). The main goal of the social and hygienic monitoring of the population is to determine the factors and the degree of influence of the living environment (habitat) on human health. The following data are collected in the course of socio-hygienic monitoring: (a) medical and demographic indicators; (b) information on the health and morbidity of the population; (c) data on the socio-economic condition of the territory; (d) data on the safety of air, drinking water, soil in populated areas; (e) contamination and content of GMOs in food and food raw materials; (f) information on working conditions and occupational diseases; and (g) radiation safety of settlements. The main goal of the social and hygienic monitoring of the population is to determine the factors and the degree of influence of the living environment (habitat) on human health. Social and hygienic monitoring is conducted by the bodies authorized to carry out the federal state sanitary and epidemiological supervision, in the order established by the Government of the Russian Federation (Decree No. 60 2006). The Federal 
Service for Consumer Protection and Human Welfare (Ministry of Health) organizes the conduct of social and hygienic monitoring in the prescribed manner (Order No. 322 2004).

Environmental and social and hygienic monitoring cover a very large list of objects under study for a very diverse range of indicators. There is a huge number of regulations that must be observed. In fact, for each object of study there is a relevant order of the Ministry, which is detailed in the departmental guidelines. This is typical of the Russian legal system, which is based on a huge number of by-laws. As a rule, federal laws establish only the basic principles of legal regulation, and the operationalization is carried out at the level of government resolutions, ministerial orders, etc. This causes difficulties both with the search for the necessary documents and with their execution. Therefore, it can be considered as one of the challenges in the implementation of the Global Monitoring Plan.

\section{Gaps in the Russian national system of POPs monitoring}

As mentioned earlier in 2014, a list of pollutants to be monitored was adopted in Russia. It includes POPs among others. This list is set up for air, water objects and soil. This means that within the framework of the national system of environmental monitoring only these three objects are monitored for POPs concentrations. At the same time, all the parties of the Convention recognized that persistent organic pollutants are transported, not only through air and water, but also by migratory species, across international boundaries and deposited far from their place of release, where they accumulate in terrestrial and aquatic ecosystems. But in Russia, the determination of the levels of concentration of persistent organic pollutants and the assessment of their impact on animals are not a priority. An approach in which the toxicological assessment of the state of the animal world does not play a primary role in the system of state environmental monitoring is to some extent justified because toxic substances often enter living organisms from the air (Hung et al. 2016), water (Kosyakov et al. 2017) and soil (AMAP 2004). At the same time, this approach does not take into account that living organisms themselves can be sources of persistent organic pollutants and not only among the objects of the animal world but also from animal to human. For decades, the human body accumulates pollutants derived from the consumption of animals, birds and fish, which may contain a large amount of such substances; that accumulation subsequently affects future generations of people (Van Oostdam et al. 2004).

In accordance with Russian environmental legislation, the animal world is a set of living organisms that includes all species of wild animals permanently or temporarily inhabiting the territory of the Russian Federation in a state of natural freedom, as well as natural resources of the continental shelf and the exclusive economic zone of the Russian Federation (Law No. 52-FZ 1995: art. 1). The state monitoring of the animal world is a system of regular observations of the range, number and physical condition of animal objects, as well as the structure, quality and area of their habitat (Law No. 52-FZ 1995: art. 15). However, there are significant limitations on the range of objects subject to observation. Implementation of state accounting, the state cadastre and the state monitoring of fauna is carried out with regard to hunting resources, fauna listed in the Red Book of the Russian Federation and Red books of subjects of the Russian Federation (Order No. 306 2016). An exception has been made for the monitoring carried out in the territories' nature reserves and national parks. In such areas, monitoring is carried out with respect to all other objects of fauna (Order No. 963 2011). 
Thus, complex observations of the state of the animal world, as well as assessments and forecasts of changes in the state of the animal world, are carried out in relation to a very limited range of objects. This limitation is due to the huge number of different species of wild animals inhabiting the territory of Russia and the limited resources of the State to extend the system of state environmental monitoring to all these species. Therefore, it would be reasonable to extend the POPs monitoring of animals only to those species that are consumed by humans. The unified system of state environmental monitoring of those species of wild animals includes monitoring of aquatic biological resources and monitoring of hunting resources and their habitats.

Monitoring of Aquatic Biological Resources is a system of regular observations of a) the range, number, quality and reproduction of aquatic biological resources that are objects of fishing, as well as their habitat; and b) fishing and conservation of aquatic biological resources (Decree No. 994 2008). Here, the object of monitoring is water resources, which supply fish. The Federal law on Fishing and Conservation of Aquatic Biological Resources defines fishing as "the activity of extraction (fishing) of aquatic biological resources", that is, all (any) species of fish, aquatic invertebrates, aquatic mammals, algae, other aquatic animals and plants in a state of natural freedom (Law No. 166-FZ 2004). Part 1 of Article 15 of this Law establishes that fishing is carried out with respect to species of aquatic biological resources, production (catch) of which is not prohibited (prohibited species are, for example, those listed in the Red book (Order No. 569 1997)).

According to legislation, the only indicator under which toxicological analyses of the concentration of persistent organic pollutants in aquatic biological resources can be carried out is "quality" (Decree No. 994 2008). Unfortunately, the document does not disclose the content of this indicator. As mentioned on the official website of the National Centre for the Safety of Aquatic Products and Aquaculture, monitoring is conducted of PCB, DDT and $\mathrm{HCH}$ concentrations in commercially caught fish (National Center 2018). However, not all laboratories involved in the state monitoring system perform such analyses because of the high cost and the special requirements for the equipment required. As seen from the above, only fish caught industrially, entering the domestic market and being exported are subject to such analyses on a regular basis. Thus, this activity is regulated by the acts of state supervision in the field of food quality and safety (Law No. 29-FZ 2000; Order No. 883 2000; Resolution No. 987 2000) and is not related to environmental monitoring as such. The controlling bodies in this area are the Federal Service for veterinary and phytosanitary surveillance (Ministry of Agriculture) and the Federal Service for consumer protection and human welfare (Ministry of Health). This state control does not cover fish and other aquatic biological resources caught by the indigenous Arctic population, as the traditional species they consume may not coincide with industrial ones, as they also include rare species of aquatic biological resources. Thus, temporal monitoring of toxicants in a variety of marine biota must be a priority (Braune et al. 2005).

State monitoring of hunting resources and their habitats entails a system of regular monitoring of (a) the amount and distribution of hunting resources, (b) their placement in the environment, (c) the condition of hunting resources and the dynamics of change by species and (d) the condition of the habitat of hunting resources and hunting areas. This monitoring is carried out using such indicators as the dynamics of change of the number of hunting resources (by species) from the beginning of the implementation of State monitoring under the auspices of the Russian Federation and the condition of hunting resources (fertility, diseases of hunting resources) (Order No. 344 2010). Actually, this is all that is monitored in relation to the hunting resources. 
These provisions indicate that to date, the legislator does not consider the animal world as a source of persistent organic pollutants for the human body. This approach greatly limits the possibility of identifying concentrations of persistent organic pollutants in the components of the natural environment; it also limits the detection of sources of pollution and does not allow the calculation of health risks for residents of the Arctic region of Russia. With migratory species of wild animals, e.g. birds, the Russian Arctic can receive pollutants that have never been produced or used in the Russian Federation and therefore cannot be found in soils or water objects. It follows that without systematic observation of such species, the transboundary transport of persistent organic pollutants cannot be complex. The indigenous peoples of the North consume wild animals, birds and fish, including their migratory species, which make up to eighty per cent of their nutrition (AMAP 2004). This category of the Arctic population is at the greatest risk of causing harm to life and health due to the constant consumption of toxic compounds (Sandanger et al. 2003).

\section{NArFU's biomonitoring initiative}

In addition to the difficulties arising from the complexities of Russian legal regulation, there are other practical problems. Russia lacks accredited laboratories that have modern equipment, consumables and the necessary competencies for analytical work with biological samples (Second Global Monitoring Report 2017). Often, biological objects collected in Russian territory must be taken abroad for analysis. Here, enormous efforts are required to obtain an official export permit, and few people want to go through the bureaucracy. Moreover, to participate in monitoring activities under the AMAP or the GMP, Russian laboratories must be able to participate in the same system of quality assurance control as foreign laboratories. Unfortunately, the language barrier (in Russia, there is still a large percentage of good scientists and analysts who do not speak English or any other foreign language) prevents access to the international scientific arena.

In 2017, a project supported by the Government of the Russian Federation to develop a methodology for biological monitoring and assessment of public health risks associated with the accumulation of persistent pollutants through food chains was launched in Arkhangelsk in the Northern (Arctic) Federal University named after M.V. Lomonosov (NArFU). The uniqueness of this project lies in the fact that under the single roof of the newly created Arctic Biomonitoring Laboratory, it became possible to gather together experts from different fields of science.

Sociologists, chemists, biologists, ecologists, physicians, economists, lawyers and specialists in mathematical modelling work together on a common task. The importance of an interdisciplinary approach is beyond doubt, as it allows us to consider the topic from different angles in order to develop a common understanding of ways to create and implement the methodology. The result of this joint work is important not only for fundamental science but also for society and the State.

This project is expected to achieve the following: (a) record the changes that are occurring in the health of the indigenous population of the Russian Arctic under the influence of persistent pollutants; (b) develop a methodology for calculating individual health risks; (c) change the legal regulations in the field to ensure constitutional rights to health and to a favourable environment; (d) determine the most likely sources of the pollutants entering the Arctic; and (e) include the Arctic Biomonitoring Laboratory in the AMAP and GMP network of Arctic monitoring activities. 
Within the governmental megagrant project mentioned above, NArFU's Arctic Biomonitoring Laboratory staff are undertaking activities such as collecting samples of fish, birds and animals consumed by the indigenous peoples of Nenets Autonomous Okrug and Chukotskiy Autonomus Okrug and analysing the inorganic and organic pollutants contained therein. Yamalo-Nenetskiy Autonomus Okrug was also interested in this work. The Laboratory has also conducted several agreements with medical institutions to select the blood samples of local residents for analysis. At the moment, the Arctic Biomonitoring Laboratory has accredited methodologies for the identification of inorganic pollutants in food samples in the Russian National Accreditation System. The next year, the Laboratory plans to accredit methodologies for the identification of organic pollutants in food samples and human blood samples. Accreditation in the National Accreditation System is of high importance for laboratories claiming to be involved in state monitoring activities. In this regard, the emergence of such a laboratory in Russia, which would meet national requirements and enter into an open dialogue and cooperation with foreign research centres and laboratories, is very important for the construction of an international unified system of monitoring in the Arctic. The presence of trustworthy laboratories in Russia, working with biological samples, will meet a very large part of the need for analytical work with this material. This will reduce the amount of biological material exported outside Russia, which is of great concern to the country's leaders (The Moscow Times 2017).

In addition to the expedition work on sampling and analytical work with the equipment, the laboratory is entitled to analyse the current state regulation in the field of Arctic biomonitoring and to develop proposals for its improvement. In this regard, the staff of the NArFU's Arctic Biomonitoring Laboratory has developed proposals to change the existing legal acts regulating this type of monitoring. In particular, it was proposed to augment the Order of Federal Service for Surveillance on Consumer Rights Protection and Human Wellbeing of 30th of December 2005 No. 810 with part 10 as follows: "Chemical contamination of migratory species of birds, fish and wild animals consumed by indigenous peoples of the North, Siberia and the Far East of the Russian Federation". This document contains templates of tables that are filled in during social and hygienic monitoring and then entered into a state database. Each section of these tables is critical to providing a complete picture of the health status of the population and their habitat. Each section of the tables is required to be filled in by the persons or organizations that are entitled to undertake this type of monitoring activities. Therefore, the collection of the necessary data and information is also becoming mandatory.

Table 1 shows the proposed table to be included in Order No. 810 (2005). This table shows which data need to be systematically collected during the socio-hygienic monitoring of indigenous peoples' health with respect to the identification of POP concentrations in their food samples. This Order will make it mandatory to carry out analyses of toxic substances in traditional indigenous food and to identify health effects. The proposed name of the table is "Presence of contaminants in migratory species of birds, fish and wild animals consumed by indigenous peoples of the North, Siberia and the Far East of the Russian Federation".

Table 1 Data that need to be systematically collected during the socio-hygienic monitoring of indigenous peoples' health with respect to the identification of POP concentrations in their food samples

\begin{tabular}{|c|c|c|c|c|c|c|c|c|}
\hline Species & Name & $\begin{array}{c}\text { Habitat } \\
\text { area }\end{array}$ & $\begin{array}{l}\text { Sampling } \\
\text { place }\end{array}$ & $\begin{array}{l}\text { Group of } \\
\text { toxicants }\end{array}$ & $\begin{array}{c}\text { Type of con- } \\
\text { taminant }\end{array}$ & $\begin{array}{c}\text { Method of } \\
\text { analysis }\end{array}$ & $\begin{array}{l}\text { Purpose } \\
\text { of study }\end{array}$ & $\begin{array}{l}\text { Actual value } \\
(\mathrm{mg} / \mathrm{kg})\end{array}$ \\
\hline
\end{tabular}


Another proposal was to add the list of pollutants approved by the government of the Russian Federation (Order No. 1316-p 2015) to the list of those contaminants that can accumulate in migratory species of birds and animals (at least those consumed by the indigenous inhabitants of the Russian Arctic). This will allow control of the levels of contamination of the environment by persistent pollutants and will enable timely assessment of the risks to public health. Such normative proposals were developed by the author of this article and sent to the Government of the Russian Federation for consideration. The Government of the Russian Federation transmitted them to the Ministry of Natural Resources and Environment. However, so far, no response has been received, most likely due to the ongoing changes in the composition of the Ministry (Staalesen 2018).

Today in Russia, there are a large number of sanitary rules and regulations governing the formation of human living conditions and the process of monitoring their implementation. However, the analysis of such acts does not allow us to conclude that in Russia today, there is a unified system of complex observations of the environmental intake of persistent organic pollutants, the dynamics of their accumulation and the impact of such substances on the health of individuals and society as a whole. The normative proposals developed by the author during the implementation of the government research project aroused great interest from the officials of the Ministry of Science and Higher Education of Russia and the governors of the Arctic regions. This corresponds to the approved Plan of Implementation of the Obligations of the Russian Federation under the Stockholm Convention on Persistent Organic Pollutants (Order No. 529 2017). This is an example of an interdisciplinary approach to research work and the practical application of the results.

\section{Conclusion}

The study showed that in the case of POPs monitoring in the Russian Arctic there are both issues of design and issues of execution. Most of these problems are relevant to the overarching challenges of monitoring relating to international environmental agreements. The problems of design include: (1) the long-lasting process of implementation of international obligations in Russian legislation; (2) differences in the understanding of basic concepts in Russia and at the international level; (3) the failure to pay sufficient attention to POPs in living resources, which form the nutrition diet of Indigenous peoples and other people. The problems of execution include: (1) complications arising from multiple laws/regulations and the plurality of bodies responsible for monitoring activities, (2) insufficiency of financial resources and trained personnel, (3) the lack of a coordinating mechanism to integrate data from different parts of the Russian Arctic, and (4) problems in harmonizing Russian data with data produced in other (Arctic) states.

Work on the implementation of the Stockholm Convention in Russia is very slow. This applies both to regulatory and practical measures. This is due to the peculiarities of the national legal system, as well as to the primacy of domestic obligations over international ones, which is revealed at the stage of implementation of federal legislation. Russian legislation and law enforcement practice is very reluctant to respond to the need to change the focus and to follow international trends and obligations. On the one hand, this is due to the size of the country, the federal division of the state and the great remoteness of the regions from each other. On the other hand, Russia's big size and slowness in monitoring POPs, particularly in the Arctic, leave huge gaps on the GMP and AMAP monitoring maps. This creates other difficulties, both for the international community and for Russia itself. Global 
problems include: (1) the inability to properly assess the effectiveness of the Stockholm Convention; (2) the inability to assess the level of pollution of Arctic ecosystems; (3) the absence of information on the presence of certain pollutants in the environment or in humans making it impossible to presume possible sources of POPs. For Russia, the main problem is the inability to identify and assess risks to public health and the environment.

In this regard, the case described above seems to be interesting as an example of a multilevel implementation of an international agreement. While the slow state machine is taking the necessary measures at the federal level ("from the top"), scientists are creating a specialized multidisciplinary laboratory (biomonitoring centre) for monitoring POPs in a concrete region, in the Russian Arctic ("from the bottom"). Such a laboratory is a help for state bodies in terms of accumulation and analysis of information on POPs in the Arctic, introduction into the international system of quality assurance, development of standard-setting proposals. Although of course, such work is impossible without state support measures and appropriate federal legal regulation. This could be an interesting example for replication to other regions of Russia and even other parties to the Stockholm Convention.

Funding Grant support of the Government of the Russian Federation in accordance with the Resolution of 9 April 2010 No. 220 (Grant No. 14.Y26.31.0009 of 14 March 2017).

\section{Compliance with ethical standards}

Conflict of interest The author declares that she has no conflict of interest.

Open Access This article is distributed under the terms of the Creative Commons Attribution 4.0 International License (http://creativecommons.org/licenses/by/4.0/), which permits unrestricted use, distribution, and reproduction in any medium, provided you give appropriate credit to the original author(s) and the source, provide a link to the Creative Commons license, and indicate if changes were made.

\section{References}

90 People. (2016). На Ямале 90 человек госпитализировали из-за сибирской язвы. [90 people were hospitalized in Yamal because of anthrax, 2016]. Российская газета. 02.08.2016. https:// rg.ru/2016/08/02/reg-urfo/do-90-chelovek-vyroslo-chislo-gospitalizirovannyh.html. Accessed 10 June 2018 .

Adlard, B., Donaldson, S. G., Odland, J. O., Weihe, P., Berner, J., Carlsen, A., et al. (2018). Future directions for monitoring and human health research for the Arctic Monitoring and Assessment Programme. Global Health Action, 11(1), 1480084.

AMAP. (1998). AMAP assessment report: Arctic pollution issues (pp. xii +859). Oslo, Norway: Arctic Monitoring and Assessment Programme (AMAP). https://www.amap.no/documents/doc/amap-asses sment-report-arctic-pollution-issues/68. Accessed 10 November 2018.

AMAP. (2003). AMAP assessment 2002: Human health in the Arctic (pp. xiv + 137). Oslo, Norway: Arctic Monitoring and Assessment Programme (AMAP). https://www.amap.no/documents/doc/amap-asses sment-2002-human-health-in-the-arctic/95. Accessed 10 November 2018.

AMAP. (2004). Persistent toxic substances, food security and indigenous peoples of the Russian North. Final Report. Arctic Monitoring and Assessment Programme (AMAP), Oslo, pp 192, AMAP Report 2004. http://www.amap.no/documents/doc/persistent-toxic-substances-food-security-and-indigenous -peoples-of-the-russian-north.-final-report/795. Accessed 10 June 2018.

AMAP. (2009). AMAP assessment 2009: Human health in the Arctic (pp. Xiv +254). Oslo, Norway: Arctic Monitoring and Assessment Programme (AMAP). http://www.amap.no/documents/doc/amap-asses sment-2009-human-health-in-the-arctic/98. Accessed 10 June 2018. 
AMAP. (2015). AMAP assessment 2015: Human health in the Arctic (pp. vii + 165). Oslo, Norway: Arctic Monitoring and Assessment Programme (AMAP). http://www.amap.no/documents/doc/amap-asses sment-2015-human-health-in-the-arctic/1346. Accessed 10 June 2018.

AMAP. (2018). AMAP assessment 2018: Biological effects of contaminants on Arctic wildlife and fish (pp. vii +84 ). Oslo, Norway: Arctic Monitoring and Assessment Programme (AMAP). https://www.amap. no/documents/doc/amap-assessment-2018-biological-effects-of-contaminants-on-arctic-wildlife-andfish-pre-print/1663. Accessed 09 October 2018.

Asmund, G., Vorkamp, K., Backus, S., \& Comba, M. (2004). An update on analytical methods, quality assurance and quality control used in the Greenland AMAP programme: 1999-2002. Science of the Total Environment, 331(1), 233-245.

Braune, B. M., Outridge, P. M., Fisk, A. T., Muir, D. C. G., Helm, P. A., Hobbs, K., et al. (2005). Persistent organic pollutants and mercury in marine biota of the Canadian Arctic: An overview of spatial and temporal trends. Science of the Total Environment, 351-352, 4-56.

Dudarev, A., \& Odland, J. (2017). Human health in connection with Arctic pollution-results and perspectives of international studies under the Aegis of AMAP. Human Ecology, 9, 3-14.

Dudarev, A. A. (2012). Dietary exposure to persistent organic pollutants and metals among Inuit and Chukchi in Russian Arctic Chukotka. International Journal of Circumpolar Health, 71(1), 18592.

Forest Code. (2006). Forest code of the Russian Federation of 4th of December 2006 No. 200-FZ.

Global monitoring report under the global monitoring plan for effectiveness evaluation. (2009). Conference of the parties of the Stockholm Convention on persistent organic pollutants. Fourth meeting, pp 20. http://www.pops.int/Implementation/GlobalMonitoringPlan/MonitoringReports/tabid/525/Defau 1t.aspx. Accessed 9 Oct 2018.

Holoubek, I., Klánová, J., Kočan, A., Čupr, P., Dudarev, A., Borůvková, J., \& Chromá, K. (2008) Global Monitoring Plan for Persistent Organic Pollutants Under the Stockholm Convention Article 16 on Effectiveness Evaluation. First Regional Monitoring Report Central and Eastern European and Central Asian Region. RECETOX MU Brno. RECETOX-TOCOEN REPORTS No. 339. September 2008, xv $+232 \mathrm{pp}+67 \mathrm{pp}$ of Annexes.

Hung, H., Katsoyiannis, A. A., Brorström-Lundén, E., Olafsdottir, K., Aas, W., Breivik, K., et al. (2016). Temporal trends of persistent organic pollutants (POPs) in arctic air: 20 years of monitoring under the Arctic Monitoring and Assessment Programme (AMAP). Environmental Pollution, 217, 52-61.

Klopov, V., Odland, J., \& Burkow, I. (1998). Persistent organic pollutants in maternal blood plasma and breast milk from Russian arctic populations. International Journal of Circumpolar Health, 57(4), 239-248.

Kosyakov, D. S., Ul'yanovskii, N. V., Popov, M. S., Latkin, T. B., \& Lebedev, A. T. (2017). Halogenated fatty amides-A brand new class of disinfection by-products. Water Research, 127, 183-190.

Law No. 164-FZ. (2011). Federal Law of 27th of June 2011 No. 164-FZ on the ratification of stockholm convention on persistent organic pollutants.

Law No. 166-FZ. (2004). Federal Law of 20th of December 2004 No. 166-FZ on fishing and conservation of aquatic biological resources.

Law No. 170-FZ. (1995). Federal Law of 21st of November 1995 No. 170-FZ on use of atomic energy.

Law No. 187-FZ. (1995). Federal Law of 30th of November 1995 No. 187-FZ on the continental shelf of the Russian Federation.

Law No. 191-FZ. (1998). Federal Law of 17th of December 1998 No. 191-FZ on exclusive economic zone of the Russian Federation.

Law No. 29-FZ. (2000). Federal Law of 2nd of January 2000 No. 29-FZ on quality and safety of food products.

Law No. 52-FZ. (1995). Federal law of 24th of April 1995 No. 52-FZ on animal world.

Law No. 52-FZ. (1999). Federal law of 30th of March 1999 No. 52-FZ on sanitary and epidemiological welfare of the population.

Law No. 7-FZ. (2002). Federal Law of 10th of January 2002 No. 7-FZ on environmental protection.

Law No. 96-FZ. (1999). Federal Law of 4th of May 1999 No. 96-FZ on protection of atmospheric air.

Lucia, M., Verboven, N., Strom, H., Miljeteig, C., Gavrilo, M. V., Braune, B., et al. (2015). Circumpolar contamination in eggs of the high-Arctic ivory gull Pagophila eburnea. Environmental Toxicology and Chemistry, 34(7), 1552-1561.

National Center for Safety of Aquatic Products and Aquaculture. (2018). Monitoring of fishing area for safety indicators of fish products. http://fishquality.ru/. Accessed 10 June 2018.

News.ru. (2017). В Кремле подтвердили, что данные о сборе иностранцами биоматериалов россиян президент Путин получает из докладов спецслужб [The Kremlin confirmed that President Putin receives reports from the secret services the data on the collection of biomaterials of Russians]. https://www.newsru.com/russia/31oct2017/putin_bio_fsb.html. Accessed 10 June 2018. 
Order No. 60. (2006). Order of the government of the Russian Federation of 2nd of February 2006 No. 60 on approval of provisions for social and hygienic monitoring.

Order No. 1316-p. (2015). Order of the government of the Russian Federation of 08.07.2015 No. 1316-p about the approval of the list of pollutants concerning which measures of state regulation in the field of environmental protection are applied.

Order No. 156. (2017). Order of ministry of natural resources of the Russian Federation of 5th of April 2017 No. 156 on approving the procedure for state forest pathology monitoring.

Order No. 219. (2007). Order of the government of the Russian Federation of 10th of April 2007 No. 219 on approval of regulations on conducting state monitoring of water objects.

Order No. 2482-p. (2016). Order of the government of the Russian Federation of 23 of November 2016 No 2482-p about the accession of the Russian Federation to the amendments to the Stockholm Convention on Persistent Organic Pollutants.

Order No. 306. (2016). Order of ministry of natural resources of the Russian Federation of 23rd of May 2016 No. 306 on approval of the procedure of conducting the Red Book of the Russian Federation.

Order No. 320. (2002). Order of the government of the Russian Federation of 18th of May 2002 No. 320 about the signing the Stockholm Convention on Persistent Organic Pollutants.

Order No. 322. (2004). Order of the government of the Russian Federation of 30th of June 2004 No. 322 about the statement of regulations on Federal service for surveillance on consumer rights protection and human wellbeing.

Order No. 344. (2010). Order of the ministry of natural resources of the Russian Federation of 6th of September 2010 No. 344 on approving the procedure for state monitoring of hunting resources and their habitat and use of its data.

Order No. 433. (2001). Order of the ministry of natural resources of the Russian Federation of 21st of May 2001 No. 433 about the statement of regulations on the procedure of implementation of the state monitoring of subsoil of the Russian Federation.

Order No. 477. (2013). Order of the government of the Russian Federation of 06.06.2013 No. 477 about implementation of the state monitoring of condition and environmental pollution.

Order No. 529. (2017). Order of ministry of natural resources of the Russian Federation from 3rd of October 2017 No. 529 on approval of the plan of implementation of the obligations of the Russian Federation under the Stockholm convention on persistent organic pollutants.

Order No. 569. (1997). Order of the state committee on ecology of the Russian Federation of 19th of December 1997 No. 569 on approving lists of objects of fauna listed in the Red Book of the Russian federation and excluded from the Red Book of the Russian Federation.

Order No. 57. (2017). Order of the government of the Russian Federation of 8 of February 2017 No. 57 about the statement of Regulations on the National focal point created for the purpose of exchange of information on implementation of the obligation of the Russian Federation provided by the Stockholm Convention on Persistent Organic Pollutants.

Order No. 583. (2002). Order of the ministry of natural resources of the Russian Federation of 18th of September 2002 No. 583 about the establishment of National focal point of the Russian Federation on the Stockholm Convention on Persistent Organic Pollutants.

Order No. 810. (2005). Order of Federal service for surveillance on consumer rights protection and human wellbeing of 30th of December 2005 No. 810 about the list of indicators and data for formation of Federal information fund of social and hygienic monitoring.

Order No. 822. (2003). Order of ministry of natural resources of the Russian Federation of 10th of September 2003 No. 822 on approval of the regulations about the national coordinating Council of the Russian Federation on the Stockholm Convention on Persistent Organic Pollutants.

Order No. 852. (2014). Order of the ministry of economic development of the Russian Federation of 26th of December 2014 No. 852 about the statement of the procedure of implementation of the state monitoring of lands, except for lands of agricultural use.

Order No. 883. (2000). Order of the government of the Russian Federation of 22nd of November 2000 No. 883 about the organization and implementation of monitoring of quality, food safety and public health.

Order No. 963. (2011). Order of the ministry of natural resources of the Russian Federation of 22nd of December 2011 No. 963 about the statement of the procedure of maintaining the state accounting, the state cadastre and the state monitoring of objects of Fauna.

Order No. 987. (2000). Order of the government of the Russian Federation of 21st of December 2000 No. 987 About the state supervision in the field of quality assurance and safety of foodstuff.

Order No. 994. (2008). Order of the government of the Russian Federation of 24th of December 2008 No. 994 on approval of regulations on conducting state monitoring of aquatic biological resources and the application of its data. 
Rigét, F., Bignert, A., Braune, B., Dam, M., Dietz, R., Evans, M., et al. (2019). Temporal trends of persistent organic pollutants in Arctic marine and freshwater biota. Science of the Total Environment, 649, 99-110.

Sandanger, T. M., Brustad, M., Odland, J. O., Doudarev, A. A., Miretsky, G. I., Chaschin, V., et al. (2003). Human plasma levels of POPs, and diet among native people from Uelen, Chukotka. Journal of Environmental Monitoring, 5(4), 689-696.

Savinov, V., Muir, D. C. G., Svetochev, V., Svetocheva, O., Belikov, S., Boltunov, A., et al. (2011). Persistent organic pollutants in ringed seals from the Russian Arctic. Science of the Total Environment, 409(14), 2734-2745.

Second Global Monitoring Report. (2017). Conference of the parties to the Stockholm Convention on persistent organic pollutants. Eighth meeting, pp 129. http://chm.pops.int/implementation/globalmoni toringplan/monitoringreports/tabid/525/default.aspx. Accessed 9 October 2018.

Šebková, K., Borůvková, J., Přibylová, P., Vrana, B., Hůlek, R., Holoubek, I., \& Klánová, J. (2014). Global Monitoring Plan for Persistent Organic Pollutants Under the Stockholm Convention Article 16 on Effectiveness Evaluation. Second Regional Monitoring Report of the Central, Eastern European and Central Asian Region. Research Centre for Toxic Compounds in the Environment, Masaryk University, Brno, Czech Republic, December 2014, pages 102+annexes, RECETOX report No. 506.

Staalesen, A. (2018). Arctic governor gets key post in Russia's new government. The Barents Observer. https://thebarentsobserver.com/en/life-and-public/2018/05/arctic-strongman-gets-key-post-russiasnew-government. Accessed 09 October 2018.

Stockholm Convention on persistent organic pollutants was adopted on 22 May 2001 in Stockholm, Sweden. http://chm.pops.int/Portals/0/Repository/convention_text/UNEP-POPS-COP-CONVTEXT-FULL. English.PDF. Accessed 09 November 2018.

The Moscow Times. (2017). Top officials express concern over foreign collection of Russian DNA. The Moscow Times. November 1, 2017. https://themoscowtimes.com/news/russia-to-tighten-control-overbiological-samples-sent-abroad-59431. Accessed 09 October 2018

Van Oostdam, J. C., Dewailly, E., Gilman, A., Hansen, J. C., Odland, J. O., Chashchin, V., et al. (2004). Circumpolar maternal blood contaminant survey, 1994-1997 organochlorine compounds. Science of the Total Environment, 330(1), 55-70.

Vlassov, V. (2007). Russian clinical research is threatened by ban on export of samples. BMJ, 334(7606), 1237.

Publisher's Note Springer Nature remains neutral with regard to jurisdictional claims in published maps and institutional affiliations. 